\title{
Nasopharyngeal Carcinoma at Otolaryngology Department Prof. R.D. Kandou Hospital Manado Indonesia
}

\author{
Olivia Pelealu ${ }^{1, *}$, Oraetlabora Palandeng ${ }^{1}$, I Putu Alland Adithia ${ }^{1}$, SutjiPratiwi Rahardjo ${ }^{2}$ \\ ${ }^{1}$ Department of Otolaryngology, Faculty of Medicine, Sam Ratulangi University, Manado, Indonesia \\ ${ }^{2}$ Department of Otolaringology, Faculty of Medicine, Hasanuddin University, Makassar, Indonesia \\ *Corresponding author: liv_dr@yahoo.com
}

Received December 20, 2014; Revised December 27, 2014; Accepted January 05, 2015

\begin{abstract}
Nasopharyngeal carcinoma (NPC) is a malignant tumor in head and neck region are derived from nasopharyngeal epithelium. NPC has the highest incidence rates in southern China. The incidence of malignancy in head and neck region as a whole has increased. Based on data obtained in the otolaryngology department in Prof. Kandou hospital Manado Indonesia, NPC is the highest ranks of malignancy in otolaryngology cancer. The etiology of NPC is complex, involving multiple factors including genetic susceptibility, Epstein Barr viral (EBV), environmental and dietary factors. Symptoms of NPC can be divided into 4 groups, nasopharyngeal, ear, eye and neurological and neck symptoms. Diagnosis of NPC is by biopsy and make histopathlogic examination Radiotherapy is the primary treatment. This research was conducted using descriptive retrospective method of data collection, from medical records and processed by means arranged in the form of tables and graphs.
\end{abstract}

Keywords: nasopharyngeal carcinoma, symptoms and sign, histopathologic

Cite This Article: Olivia Pelealu, Oraetlabora Palandeng, I Putu Alland Adithia, and SutjiPratiwi Rahardjo, "Nasopharyngeal Carcinoma at Otolaryngology Department Prof. R.D. Kandou Hospital Manado Indonesia." American Journal of Medical Sciences and Medicine, vol. 3, no. 1 (2015): 1-3. doi: 10.12691/ajmsm-3-1-1.

\section{Introduction}

Nasopharyngeal carcinoma (NPC) is a malignant tumor in head and neck region are derived from nasopharyngeal epithelium. The location of this cancer is at Rossenmuleri fold behind the eustachian tube at nasopharyng [1,2] .

Incidence of head and neck cancer is increase, including nasopharyngeal carcinoma. The patients who came with the sign of nasopharyngeal carcinoma in ear nose and throat must have further examination. [3,4] Incidence in Japan and India is 0,5 - 1/100.000 population in a year, it is the same as in Europe and North America. Higher incidence has found in North China, Mediteranian, North Africa and Southeast Asia, 5-9/100.000 population. The highest incidence is in South China, is 10$150 / 100.000$ population in a year $[5,6,7,8]$.

Incidence of Nasopharyngeal carcinoma in the several region in Indonesia is not really differrent. [1] Otolaryngology department, medicine faculty of Indonesia University, found more than 100 cases of NPC in a year. Otolaryngology department medicine faculty of Sam Ratulangi University has found 110 cases of NPC in three years [5,7].

Etiology of NPC is Epstein Barr (EB) viral infection. All NPC patients found increasing of EB viral, higher than the normal people. EB viral it's not the only factor but there were other risk factor like geography, race, sex, genetic, occupation, environment, way of life, culture, social economy and infection $[1,3]$.

Histopathologic classification of NPC are type 1 keratinizing squamous cell carcinoma, type 2 non keratinizing squamous cell carcinoma and type 3 undifferentiated carcinoma [9].

Symptoms and sign of NPC divided into 4 groups. Nasopharyngeal symptoms are epistaxis and blocking nose. [1,7] Ear symptoms are tinitus, otalgia, hearing decrease and otitis media. This symptom occured because tumor has infiltrate the Eustachian tube region. [1,3] Eye and neurologic symptoms are occured if the tumor infiltrate the lacerum and jugulare foramen and infiltrate the III, IV, V, VI, IX, X, XI, XII. [1] The last is metastatic symptom or neck tumor. Usually patients came to the hospital because of this symptoms [1,7].

Diagnosed of NPC is by doing radiologic or endoscopyc examination, but the gold standard diagnosed is biopsy too examine the tissue and histopathologic. [1,10] Therapy of NPC are radiotherapy, chemotheraphy and both. Theraphy adjuvant is neck disection, tetracycline, interferon, anti viral and vaccine [1,11].

\section{Material and Methods}

This research was conducted using descriptive retrospective method of data collection. Data were collected from medical records and processed by means arranged in the 
form of tables and graphs. Data is presented as frequency distribution of years when patients came to outpatient department, sex, age, occupation, symptoms, sign and histopathological of NPC.

\section{Results}

Patients that diagnosed as nasopharyngeal carcinoma at otolaryngology department Prof. Kandou hospital period of 2009 January - 2011 December are 52 patients. We found 12 patients in 2009 (0,29\%), 15 patients in 2010 $(0,25 \%)$ and 25 patients in 2011 (0,47 \%). The highest incidence is in 2011.

Table 1. NPC patients in 2009 - 2011

\begin{tabular}{llll}
\hline Year & Patients & NPC Patients & $\mathbf{\%}$ \\
\hline 2009 & 4.031 & 12 & 0,29 \\
2010 & 5.914 & 15 & 0,25 \\
2011 & 5.297 & 25 & 0,47 \\
Total & $\mathbf{1 5 . 2 4 2}$ & $\mathbf{5 2}$ & $\mathbf{0 , 3 4}$ \\
\hline
\end{tabular}

The result of this research is male NPC Patientsis more than female. Male NPC patients is more than female in every year, 8 in 2009, 10 in 2010 and 14 in 2011. Female NPC patients is 4 in 2009, 5 in 2010 and 11 in 2011. The percentage of male and female NPC patients is $62 \%$ : $38 \%$, almost 2:1.

Table 2. Frequency of NPC patients according to sex

\begin{tabular}{llllll}
\hline Sex & $\mathbf{2 0 0 9}$ & $\mathbf{2 0 1 0}$ & $\mathbf{2 0 1 1}$ & $\mathbf{n}$ & $\mathbf{\%}$ \\
\hline Male & 8 & 10 & 14 & 32 & 62 \\
Female & 4 & 5 & 11 & 20 & 38 \\
Total & $\mathbf{1 2}$ & $\mathbf{1 5}$ & $\mathbf{2 5}$ & $\mathbf{5 2}$ & $\mathbf{1 0 0}$ \\
\hline
\end{tabular}

Distribution of age in NPC patients shows that NPC not found in all ages, only from the age over 18 years old. The highest distribution is found in age 41-65, 32 patients in 3 years $(61,5 \%)$. Youngest patient is 18 years old and the oldest patients is 76 years old.

Table 3. NPC in distribution of ages

\begin{tabular}{llllll}
\multicolumn{7}{c}{ Table 3. NPC in distribution of ages } \\
\hline Years & $\mathbf{2 0 0 9}$ & $\mathbf{2 0 1 0}$ & $\mathbf{2 0 1 1}$ & $\mathbf{n}$ & $\mathbf{\%}$ \\
\hline $0-5$ & - & - & - & - & 0 \\
$6-11$ & - & - & - & - & 0 \\
$12-17$ & - & - & - & - & 0 \\
$18-40$ & 2 & 4 & 8 & 14 & 27 \\
$41-65$ & 9 & 7 & 16 & 32 & 61,5 \\
$\geq 65$ & 1 & 4 & 1 & 6 & 11,5 \\
Total & $\mathbf{1 2}$ & $\mathbf{1 5}$ & $\mathbf{2 5}$ & $\mathbf{5 2}$ & $\mathbf{1 0 0}$ \\
\hline
\end{tabular}

The results from the occupation of NPC patients, the highest is farmer $21 \%$ and housewife $19 \%$. The least is driver $2 \%$ and teacher $4 \%$

Table 4. Distribution of occupation in NPC

\begin{tabular}{llllll}
\hline Occupation & $\mathbf{2 0 0 9}$ & $\mathbf{2 0 1 0}$ & $\mathbf{2 0 1 1}$ & $\mathbf{n}$ & $\mathbf{\%}$ \\
\hline Farmer & 6 & 2 & 3 & 11 & 21 \\
Retired & 1 & 2 & 3 & 6 & 12 \\
Housewife & 4 & 1 & 5 & 10 & 19 \\
Driver & 1 & - & - & 1 & 2 \\
Employee & - & 1 & 6 & 7 & 13 \\
Private & - & 3 & 3 & 6 & 12 \\
Teacher & - & 2 & - & 2 & 4 \\
Jobless & - & 4 & 5 & 9 & 17 \\
Total & $\mathbf{1 2}$ & $\mathbf{1 5}$ & $\mathbf{2 5}$ & $\mathbf{5 2}$ & $\mathbf{1 0 0}$ \\
\hline
\end{tabular}

Symptoms and sign in NPC that found in result of this research was neck tumor (50\%), epistaxis (23\%) and hearing decrease (19\%).

Table 5. NPC Sign and Symptoms

\begin{tabular}{lll}
\hline Sign and Symptoms & $\mathbf{N}$ & $\mathbf{\%}$ \\
\hline Epistaxis & 12 & 23 \\
Blocking Nose & 9 & 17 \\
Hearing decrease & 10 & 19 \\
Otalgia & 4 & 8 \\
Neck Tumor & 26 & 50 \\
Headache & 5 & 10 \\
Pain on swallowing & 5 & 10 \\
Diplopia & 2 & 4 \\
Decrease of sight & 3 & 6 \\
\hline
\end{tabular}

The result of this research there was 52 NPC patients, and just 5 patients who have taken biopsy and have histopatologic result. Histopatologic result is non keratinizing squamous cell carcinoma (8\%).

Table 6. NPC Histopathologic Result

\begin{tabular}{lll}
\hline Histopathologic Result & $\mathbf{N}$ & $\mathbf{\%}$ \\
\hline Keratinized squamous cell carcinoma & 1 & 2 \\
Non keratinized quamous cell carcinoma & 4 & 8 \\
No histopathologic result & 47 & 90 \\
Total & $\mathbf{5 2}$ & $\mathbf{1 0 0}$ \\
\hline
\end{tabular}

\section{Discussion}

The result of this research has found there were 52 NPC patients (0,34\%) in 3 years (2009-2011). NPC patients increased at year 2011 and was the highest incidence that we found $(0,46 \%)$. Its the same as data from reference that found Incidence of head and neck cancer is increase including nasopharyngeal carcinoma $[3,4]$.

This research found that incidence of male is higher than female, almost 2:1. Male is $62 \%$ and female is $38 \%$. Some references found data the same as this result, male NPC patients is more than female patients. The risk factors of NPC is smooking, but smooking is not the only risk factor that has a role in NPC but many risk factors can make the NPC occured. [3,10,12] Percentage of NPC is higher in male due to different occupation and way of life. Male's contact with carcinogenic is higher than female. Cigarette and alcohol is one of the etiology we found in NPC [13].

The result of NPC in patients year, we found this result is likely from research in Padang that found 32,74 \% in age 40-49 and the results of Prof Kandou hospital before in period $2001-2003$ is $22,86 \%$ in age $50-59$ years old $[14,15]$.

There is a relation between EB viral with the highest NPC occured in age 41-65, because of the infection of this viral begins in children phase and occured in mild symptoms. After infection usually Epstein Barr viral will live in the patients body. The accumulation of the viral in body is the major role in NPC etiology. So the older the people, the more viral in the body, that make they have the highest risk factor to NPC. NPC is not occured only from one risk factors but many risk factors because cancer caused by multiple factorial. [3,16,17] Epstein Barr viral infection have latent phase about 20-25 years to maintain 
the viral in infected nasopharyngeal cells without symptoms. The infection makes cancer cells occured. It makes normal cells transformed into cancer cells due to spontaneus mutation or because carsinogenic mutation $[18,19]$.

Beside infection of EB viral, there is carcinogenic material as another risk factor. First contact to carcinogenic untill it become cancer needs longer time for induction, its $15-30$ years. EB viral infection has provided target cells in nasopharyng that susceptible to environment carcinogenic shelf and genetic mutation. Oncogen and tumor supressed gen have a role in transformation of normal cells to cancer cells. This proccess happend after latent infection, so it makes nasopharyngeal carcinoma occured mostly in year of 40 untill 60 years old [18,19].

The other risk factors from NPC are occupation and the way of life. This disease is have relation with the low salary occcupation, patient with low economic and the habit of cooking with some flavor, that maybe have relation with the housewife profession. [1,10] House with no good ventilation and full of smoke in China, Indonesia and Kenya, are risk factors for nasopharyngeal carcinoma. In Hongkong the incense smoke have a role in nasopharyngeal carcinoma [20].

Symptoms and signs of NPC are more clearly in late stage, when occure the neck tumor. Neck tumor occured because of metastatic of NPC in lymph nodes. Neck tumor is the most found sign because of there was many of lymph nodes in neck region. It's the reason patients come to the hospital [11].

Histopathologic result is the same as data from WHO that shows that $95 \%$ histopatologic result is non differentiated carcinoma, a part of keratinizing carcinoma. [12] Not all NPC patients have histopatologic result because they refuse to do biopsy because social economic problems. The diagnostic of the NPC patients is from the symptoms, sign and endoscopy.

\section{Conclusion}

The result of this research is there were 52 NPC patients in 3 years, and it increased. NPC is found more in male than female. The age of 50-59 is the most highest frequency of NPC and there was no patients under 18 years old. The highest frequency of occupation is farmer. The symptoms and sign that have higher frequency is neck tumor, epistaxis and hearing deacrease. Non keratinized squamous cell carcinoma is the most histopathologic result that found in this research.

\section{References}

[1] Roezin A, Adham M. Tumor of Otolaryngology. In: Soepardi EA, Iskandar N, Bashiruddin J, Restuti RD, editors. Teaching book of
Otolaryngology Head and Neck. $6^{\text {th }}$ Edition. Jakarta: Faculty of medicine, University of Indonesia: 2007. p. 182-7.

[2] Susworo R. Nasopharyngeal Cancer, Epidemiology and The Very Latest Treatment. Jakarta: Medical Mirror nu. 144, 2004. p. 16-8.

[3] Adams GL. Head and Neck Cancers. In: Wijaya C, linguists; Effendy H, Santosa RAK, editors: BOIES Otolaryngology Teaaching Book. $6^{\text {th }}$ Edition. Jakarta: EGC, 1997. p. 429-43.

[4] Her C. Nasopharyngeal Cancer and The Southeast Asian Patient. American family Physician 2001: 63: 1776-82.

[5] Ballenger JJ. The Diseases of Otolaryngology Head and Neck. First book. $13^{\text {th }}$ Edition. Jakarta: Binarupa Aksara; 2006. p. 318-27; 371-96.

[6] Coleman JJ, Juerkiewicz MJ. Head and Neck. In: Andrianto P, linguists; Ronardy DH, editor. Surgery Teaching Book of Sabiston. Second book. Jakarta: EGC, 2010, p, 342.

[7] Schwartz SI, Shires GT, Spencer FC, Husser WC. Head and Neck Tumors. In : Laniyati, Kartini A, Wijaya C, Komala S, Ronardy $\mathrm{DH}$, linguists;Chandranata L, Kumala P, editors. Abstract of Principles of Surgery. $6^{\text {th }}$ Edition. Jakarta: EGC, 2000. p. 252-3.

[8] Munir M. Cancer in Otolaryngology. In: Soepardi EA, Iskandar N, Bashiruddin J, Restuti RD, editors. Teaching book of Otolaryngology Head and Neck. $6^{\text {th }}$ Edition. Jakarta: Faculty of medicine, University of Indonesia: 2007. p. 172.

[9] Palandeng OI. Comparison Experiment Between Result of Swab Examination and Blind Biopsy in Nasopharyngeal Carcinoma After Radiotherapy. University of Airlangga, 2005. p. 21-3.

[10] Asroel HA. Radiotherapy Treatmentin Nasopharyngeal Carcinoma. Medan: Medicine of Faculty, Sumatera Utara University, 2002. p. $1-11$.

[11] Townsend CM, Beauchamp RD, Evers BM, Mattox KL. Head and Neck. In: Hartanto H, Asrouddin M, Nasrani CH, linguists; Rendy L, editor. Surgery Teaching Book of Sabiston. $17^{\text {th }}$ Edition. Jakarta: EGC, 2010. p. 405.

[12] Nasution I. The relationship between Smooking and Nasopharyngeal Carcinoma. Medan: Medicine of Faculty, Sumatera Utara University, Respiratory 2008. p. 6,7,12.

[13] Charactheristic of Ear Nose Throat Head and Neck cancer at Otolaryngology department RSUP Adam Malik Medan. Access from:

http://repository.usu.ac.id/bitstream.123456789.31042/4/chapter\% 2011.pdf.

[14] Padang MS. Nasopharyngeal Carcinoma patients Profile in Out Patients Department at Prof. R. D. Kandou Manado Hospital period 2006 January - 2008 Desember. Manado: Faculty of Medicine, Sam Ratulangi University. 2008, p. 26-8.

[15] Pondaag VV. Nasopharyngeal Carcinoma patients Profile in Out Patients Department at Prof. R. D. Kandou Manado Hospital period 2001 January - 2003 Desember. Manado: Faculty of Medicine, Sam Ratulangi University. 2004, p. 26-7.

[16] Cynthia F. Norris. Lymphadenopathy. In: Pendit BU, Hartawan B, Iqbal M, Yurita, linguists; Maharani DA, Susi N, editors. Pediatrician Clinical Guidance. Jakarta: EGC, 2004. p. 511.

[17] Rusdiana. The Relationship Between Anti Epstein-Barr Viral Antibody (EBNA-1) with Nasopharyngeal Carcinoma in Batak race patients in Medan.Pada Pasien Etnis Batak di Medan. Medicine of Faculty, Sumatera Utara University, 2007. p. 26-7.

[18] Harahap MPH. Vascular Endothelial Growth Factor Expression in Nasopharyngeal Carcinoma. Medicine of Faculty, Sumatera Utara University.

[19] Delfitri M. Association between Gen Alelle HLA-DQBI with Susceptibility in Batak Race in Nasopharyngeal Carcinoma. Medicine of Faculty, Sumatera Utara University

[20] McDermott AL, Dutt SN, Watkinson JC. 2001. The Aetiology of Nasopharyngeal Carcinoma. Clinical Otolaryngology. $26^{\text {th }}$ Edition. p. 89-92. 